\title{
Impact of Irrigation Intervals and Fertilization on Actual Evapotranspiration and Wheat Production
}

\author{
Manal A. El-Nady* and A. A. Shalaby** \\ * Soil Sciences Department, Faculty of Agriculture, Cairo \\ University, Giza and ${ }^{* *}$ Soil Chemistry and Physics \\ Department, Desert Research Center, Cairo, Egypt.
}

\begin{abstract}
$\mathbf{F}$ IELD experiments were conducted in clay loam soil during two successive seasons 2010/2011 and 2011/2012 at the Agricultural Experimental station, Faculty of Agriculture, Cairo University to investigate the impact of 4 irrigation frequencies combined with three fertilizers as well as control treatment (without fertilizer) on actual evapotranspiration (ETa), grain yield (Triticum aestivum, L. Sids1) and water use efficiency (WUS) of wheat under furrow irrigation system and Giza region conditions. The results clearly revealed that increasing irrigation frequency significantly decreased seasonal ETa values during studied growing seasons. While, the addition of inorganic and organic fertilizers to the studied soil significantly increased seasonal ETa compared to the control treatment (without fertilizers). The wheat crop irrigated by short irrigation interval $\leq 14$ days with fertilization by combined between inorganic and organic fertilizers increased seasonal ETa values. While, the wheat crop irrigated by the long irrigation interval of 18 days with separately organic fertilizer decreased seasonal ETa value. The results revealed that irrigation interval every 10 days with combined fertilizers treatment had the highest seasonal ETa value $(44.56 \mathrm{~cm})$, while the irrigation interval every 18 days with separately organic fertilizer had the lowest seasonal ETa value $(37.79 \mathrm{~cm})$ compared to the control treatment (without fertilizers) during studied growing seasons. The results noticed that the effect of irrigation frequencies significantly influenced the grain yield for studied growing seasons. Wheat grain yield values increased by increasing irrigation interval from 10 to 14 days. However, the increasing irrigation interval to 18 days decreased wheat grain yield. The wheat grain yield values significantly increased by addition of combined inorganic and organic fertilizers to the studied soil compared with the control treatment (without fertilizers) during studied growing seasons. The wheat crop irrigated by the short irrigation interval of 14 days with fertilization by combined between inorganic and organic fertilizers increased grain yield values, while, irrigated by the long irrigation interval more than 14 days with separately organic fertilizer decreased grain yield values. Generally, the results showed that increasing irrigation frequency significantly decreased the water use efficiency values of wheat crop during studied growing seasons. The addition of inorganic and organic fertilizers to the studied soil significantly increased wheat WUS compared to the control treatment (without fertilizers). The interaction between
\end{abstract}


irrigation frequencies and fertilizers types on water use efficiency values of wheat crop was no significant effect. The wheat crop irrigated by short irrigation interval of 14 days with fertilization by combined between inorganic and organic fertilizers increased wheat WUS values, while, irrigated by the long irrigation interval of 18 days with separately organic fertilizer decreased WUS values. Consequently, under furrow irrigation system and Giza region conditions, the irrigation interval of wheat plants must be short interval of 14 days with fertilization by combined between inorganic and organic fertilizers in clay loam soil.

Keywords: Wheat, Water use efficiency, Actual evapotranspiration, Irrigation frequency, Organic and inorganic fertilizers.

Wheat is a very important crop in Egypt. However, its production is not sufficient the local consumption. The production of wheat is mainly depending on the irrigation amount, the time of applied irrigation water, growth stage and fertilization management.

Hussain and Al-Jaloud (1995) reported that the irrigation water amount with high application rate of fertilizers increased the agricultural production of wheat crop.

Majumdar (2002) stated that applied irrigation water before the time of actual crop need encourage losses of water through higher evapotranspiration and deep percolation. Moreover, the delayed irrigation subjected the plant to water and salt stresses, consequently, the growth activities and yield reduced. Information on optimal scheduling of limited amounts of water to maximize yields of high quality crops is essential if irrigation water is to be used most efficiently ( $\mathrm{Al}$ - Kaisi et al.,1997). Therefore, it is essential to develop the most suitable irrigation schedule for different regions, especially as plant water consumption during plant growth depends mostly on soil and climatic conditions (Nath et al., 2001).

Evapotranspiration is basic information required for irrigation scheduling and for crop growth. Knowledge of evapotranspiration under different irrigation frequencies allows improved water management by adjusting the irrigation amount to meet the crop requirements for each irrigation interval. Norwood (2000) reported that irrigation water can be conserved and yields maintained by using appropriate irrigation timing to avoid plant water deficit stress at critical growth stages. Irrigation scheduling has been described as the primary tool to improve water use efficiency, increase crop yields, increase the availability of water resources, and provoke a positive effect on the quality of soil and ground water (FAO, 1996). Also, Kang et al. (2002) indicated that the responses of grain yield and water use efficiency to irrigation varied considerably due to differences in soil water contents and irrigation schedules.

Kijne et al. (2003) reported that the most effective practice to regulate the water use efficiency was through irrigation regimes. For reducing water use it is

Egypt. J. Soil Sci. 54, No. 4 (2014) 
necessary to examine the possibility of further reducing irrigation applied by optimizing the irrigation scheduling (Zhang, et al., 1999).

Van Duivenbooden et al. (1996) stated that the supply of nutrients, in a suitable form, is also a major factor determining cereal production. The influence of organic matter on soil fertility and physical fertility is well known. Khadr et al. (2002) reported that soil organic matter has affected soil chemical, physical and biological properties that in turn contributed to improve crop yield. Organic fertilizers are considered as the most important factor in reducing the application of inorganic fertilizers; consequently, reduce the adverse environmental impact of chemicals major (Marschner, 1995). It was noticed that combined application of organic and inorganic fertilizers can increase the activities of soil available nutrient content ( $\mathrm{He}$ and $\mathrm{Li}, 2004)$. It was also reported that neither inorganic nor organic amendments separately can maintain organic matter status of soil and sustain the productivity (Prasad, 1996). The proper fertilization improved water use efficiency (Pala et al., 2007).

The objective of the current study was to investigate the influence of different irrigation frequencies combined with different fertilizers on actual evapotranspiration, water use efficiency and grain yield of wheat.

\section{Material and Methods}

Field experiment was conducted at the Agricultural Experimental station, Faculty of Agriculture, Cairo University in Giza region during two successive seasons 2010/2011 and 2011/2012. The Experimental station is located at latitude of $30^{\circ} 03^{\prime \prime} \mathrm{N}$ and longitude of $31^{\circ} 13^{\prime \prime} \mathrm{E}$. The physiochemical properties of the soil experimental site are illustrated in Table 1 . The soil was classified as clay loam (41\% sand, $29 \%$ silt and $30 \%$ clay) with $1.27 \mathrm{~g} / \mathrm{cm}^{3}$ bulk density. Particle size distribution and bulk density were determined accordingly Kulte (1986). The soil chemical properties were determined according to Page (1982).

Wheat seeds (Triticum aestivum, L. Sids1) were planted at rate $70 \mathrm{~kg} / \mathrm{fed}$ on November $26^{\text {th }}$ and $24^{\text {th }}$ and were harvested at the end of April for studied seasons. The agronomic practices followed as recommended wheat production in Giza region. Furrow irrigation system was used in this investigation. The field experiment at the growing season was consisted of 48 experimental plots of 4 irrigation frequencies and 3 fertilizers types as well as control treatment (without fertilizers) with 3 replications. The irrigation frequencies were assigned to the main plots and the fertilizer types were assigned to the subplots. The experimental plot area was $5.0 \mathrm{~m} \times 12 \mathrm{~m}$ with a border of $1.5 \mathrm{~m}$ between plots. The layout of the experiment was a completely randomized in split plot design with three replicates. The field experiment was comprised 16 treatments combined between 4 irrigation treatments and 4 fertilizer treatments. 
TABLE 1. Some physiochemical properties of soil of the experimental site.

\begin{tabular}{|c|c|c|c|}
\hline \multirow{2}{*}{ Soil properties } & \multicolumn{3}{|c|}{ Soil depth, cm } \\
\hline & $0-20$ & $20-40$ & $40-60$ \\
\hline Soil moisture content at $-33 \mathrm{kPa}, \%$ & 36.85 & 34.72 & 32.34 \\
\hline Soil moisture content at $-1500 \mathrm{kPa}, \%$ & 19.52 & 18.63 & 15.48 \\
\hline Sand, $\%$ & 40.79 & 42.15 & 49.61 \\
\hline Silt, \% & 28.85 & 31.26 & 20.10 \\
\hline Clay, \% & 30.36 & 26.59 & 30.29 \\
\hline Soil textural class & C. L & C. L & $\mathrm{L}$ \\
\hline Bulk density, $\mathrm{gm} \mathrm{cm}^{-3}$ & 1.27 & 1.29 & 1.35 \\
\hline $\mathrm{ECe}, \mathrm{dSm}^{-1}$ & 1.82 & 2.13 & 1.65 \\
\hline $\mathrm{pH}$ & 7.87 & 8.02 & 8.12 \\
\hline OM. \% & 1.92 & 1.64 & 1.23 \\
\hline
\end{tabular}

\section{Irrigation treatments}

Four irrigation frequencies: the wheat plants were irrigated every 10, 12, 14 and 18 days (T10, T12, T14 and T18).

\section{Fertilizers treatments}

- Control treatment without fertilizers (NF).

- The separately inorganic fertilizers with nitrogen, phosphorus and potassium (IF) were added in the form of ammonium nitrate $(33.5 \% \mathrm{~N})$ at a rate of 75 $\mathrm{kg} / \mathrm{fed}$ in two doses, one third was added at planting date and the other two thirds were applied after planting by 35 days. Potassium sulphate (48\% $\left.\mathrm{K}_{2} \mathrm{O}\right)$ at a rate of $50 \mathrm{~kg} /$ fed and super phosphate $\left(15.5 \% \mathrm{P}_{2} \mathrm{O}_{5}\right)$ at a rate of $100 \mathrm{~kg} / \mathrm{fed}$, were applied as one dose before planting date.

- The separately organic fertilizer (OF) was applied as farmyard manure at a rate of 20 ton/fed before planting date by two weeks.

- Combined fertilizers treatment (CF) included $1 / 2$ dose of inorganic and $1 / 2$ dose of organic studied fertilizer.

Wheat grain yield, ton/fed, were determined at the end of the harvesting growth stage. The volumetric soil moisture content was determined after and before irrigation time for different studied soil depths and the actual evapotranspiration was calculated accordingly (Hansen et al., 1979) using the following equation,

$$
\mathrm{ETa}=\left(\left(\theta_{2}-\theta_{1}\right) / 100\right) \times \mathrm{D}
$$

Where, ETa is the actual evapotranspiration, mm/day. The $\theta_{2}$ and $\theta_{1}$ are the volumetric soil moisture content after and before irrigation and D is soil depth, $\mathrm{mm}$.

Water use efficiency of wheat crop (WUE) was calculated according to Giriappa (1983) using the following equation,

$$
\text { WUE }=\text { yield } / \text { ETa, }
$$

Egypt. J. Soil Sci. 54, No. 4 (2014) 
Where, yield is the wheat grain in $\mathrm{kg} / \mathrm{fed}$ and ETa is actual evapotranspiration during wheat growing season, $\mathrm{m}^{3} / \mathrm{fed}$.

The reference evapotranspiration (ETo), $\mathrm{mm} /$ day, is calculated using CROPWAT 8 computer program using Penman-Monteith equation using meteorological data of Giza station during studied growing seasons (Table 2). The duration and the crop factor of wheat stages were 20, 40, 64 and 30 days and $0.4,0.80,1.2$ and 0.7 for initial, development, flowering and harvesting growth stages, respectively, according to Allen et al. (1998).

Analysis of variance was used to test the degree of variability among the obtained data. Least significant difference (LSD) test was used for the comparison among treatments means (Sendecor and Cocheran, 1980). Cohort computer program was used for the statistical analysis, version 6.400 .

TABLE 2. Meteorological data and reference crop evapotranspiration, $\mathbf{m m} / \mathbf{d a y}$, at Giza station during studied growing seasons.

\begin{tabular}{|c|c|c|c|c|c|c|c|c|c|c|}
\hline \multirow[b]{2}{*}{ Month } & $\begin{array}{c}\text { T-max } \\
{ }^{\circ} \mathrm{C}\end{array}$ & $\begin{array}{c}\text { T-min } \\
{ }^{\circ} \mathrm{C}\end{array}$ & $\begin{array}{c}\text { R.H } \\
\%\end{array}$ & $\begin{array}{c}\mathrm{W} . \mathrm{S} \\
\mathrm{m} / \mathrm{sec}\end{array}$ & $\begin{array}{c}\text { ET }_{\mathbf{0}} \\
\mathbf{m m} / \text { day }\end{array}$ & $\begin{array}{c}\text { T-max } \\
{ }^{\circ} \mathrm{C}\end{array}$ & $\begin{array}{c}\text { T-min } \\
{ }^{\circ} \mathrm{C}\end{array}$ & $\underset{\%}{\text { R.H }}$ & $\begin{array}{c}\text { W.S } \\
\text { m/sec }\end{array}$ & $\begin{array}{c}* \mathbf{E T}_{\mathbf{0}} \\
\mathbf{m m} / \text { day }\end{array}$ \\
\hline & \multicolumn{5}{|c|}{ Season 2010/2011 } & \multicolumn{5}{|c|}{ Season 2011/2012 } \\
\hline Nov. & 27.4 & 16.1 & 68 & 1.2 & 2.78 & 24.5 & 13.3 & 65 & 1.3 & 2.50 \\
\hline Dec. & 22.8 & 10.2 & 65 & 0.9 & 2.14 & 21.7 & 10.1 & 68 & 1.5 & 2.05 \\
\hline Jan. & 21.2 & 9.7 & 68 & 0.9 & 1.84 & 19.2 & 8.3 & 61 & 1.4 & 2.08 \\
\hline Feb. & 22.9 & 11.3 & 57 & 1.3 & 2.84 & 20.7 & 9.0 & 59 & 1.4 & 2.69 \\
\hline Mar. & 24.8 & 11.9 & 57 & 1.8 & 3.98 & 23.6 & 11.3 & 61 & 1.8 & 3.76 \\
\hline Apr. & 28.4 & 18.5 & 51 & 1.4 & 4.96 & 30.7 & 15.9 & 51 & 1.8 & 5.48 \\
\hline
\end{tabular}

*ETo was calculated according to Penman-Monteith equation.

\section{Results and Discussion}

Effect of irrigation frequencies and fertilizer types on seasonal ETa

Concerning the effects of applied irrigation frequencies on seasonal ETa, $\mathrm{cm}$, during 2010/2011 and 2011/2012 growing seasons under furrow irrigation system are illustrated in Table 3. Also, the regression analyses were determined between irrigation frequency time by days $(\mathrm{T})$ and seasonal $\mathrm{ETa}, \mathrm{cm}$, under all treatment during studied growing seasons by CoHort computer program version 6.400. A highly significant relation was obtained with multiple regression coefficient is equal $0.619(\mathrm{n}=95)$. This relation is illustrated in Fig.1 and expressed in the following polynomial regression equation,

$$
\mathrm{ETa}=-0.0436 \mathrm{~T}^{2}+0.5871 \mathrm{~T}+42.0191
$$

The results clearly revealed that increasing irrigation frequency significantly decreased seasonal ETa values during studied growing seasons. The seasonal ETa average ranged between 43.4 and 38.1 and 43.8 to $38.8 \mathrm{~cm}$ for first and second growing seasons, respectively (Table 3 and Fig. 1). The highest value of seasonal ETa 
was obtained at irrigation every 10 days and the lowest value was obtained at irrigation every 18 days. The lowest seasonal ETa value might be attributed to the applied irrigation water amount was insufficient for the water requirements of wheat crop. The percentage decrease of seasonal ETa values at irrigation every 12, 14 and 18 days relative to the irrigation every 10 days were $2.3,4.0 \& 12.2 \%$ and $1.7,4.3 \&$ $11.3 \%$ for first and second growing seasons, respectively.

TABLE 3. Actual evapotranspiration, grain yield, and WUS of wheat crop as affected by irrigation frequencies and fertilizer types during studied seasons.

\begin{tabular}{|c|c|c|c|c|c|c|c|}
\hline \multirow{2}{*}{$\begin{array}{l}\text { Irrigation } \\
\text { frequency }\end{array}$} & \multirow{2}{*}{$\begin{array}{l}\text { Fertilizer } \\
\text { type }\end{array}$} & $\begin{array}{c}\text { ETa } \\
\text { cm }\end{array}$ & $\begin{array}{l}\text { Grain } \\
\text { yield } \\
\text { ton/fed }\end{array}$ & $\begin{array}{l}\text { WUS } \\
\mathrm{kg} / \mathrm{m}^{3}\end{array}$ & $\begin{array}{l}\text { ETa } \\
\mathbf{c m}\end{array}$ & $\begin{array}{c}\text { Grain } \\
\text { yield } \\
\text { ton/fed }\end{array}$ & $\begin{array}{l}\text { WUS } \\
\mathrm{kg} / \mathrm{m}^{3}\end{array}$ \\
\hline & & \multicolumn{3}{|c|}{ Season $2010 / 2011$} & \multicolumn{3}{|c|}{ Season $2011 / 2012$} \\
\hline \multirow{5}{*}{$\mathrm{T} 10$} & $\mathrm{NF}$ & 41.10 & 1.98 & 1.15 & 41.54 & 2.07 & 1.19 \\
\hline & IF & 44.19 & 2.45 & 1.32 & 44.65 & 2.50 & 1.33 \\
\hline & $\mathrm{OF}$ & 43.60 & 2.36 & 1.29 & 43.46 & 2.43 & 1.32 \\
\hline & $\mathrm{CF}$ & 44.56 & 2.49 & 1.33 & 45.43 & 2.56 & 1.34 \\
\hline & Mean & 43.363 & 2.321 & 1.272 & 43.770 & 2.389 & 1.295 \\
\hline \multirow{5}{*}{$\mathrm{T} 12$} & $\mathrm{NF}$ & 38.71 & 1.99 & 1.23 & 39.58 & 2.11 & 1.28 \\
\hline & IF & 43.86 & 2.48 & 1.34 & 44.15 & 2.63 & 1.36 \\
\hline & $\mathrm{OF}$ & 42.79 & 2.39 & 1.35 & 43.46 & 2.47 & 1.35 \\
\hline & $\mathrm{CF}$ & 44.17 & 2.52 & 1.36 & 44.87 & 2.58 & 1.37 \\
\hline & Mean & 42.383 & 2.344 & 1.315 & 43.015 & 2.448 & 1.339 \\
\hline \multirow{5}{*}{ T14 } & $\mathrm{NF}$ & 37.58 & 2.13 & 1.35 & 38.04 & 2.19 & 1.37 \\
\hline & IF & 43.15 & 2.64 & 1.46 & 43.28 & 2.67 & 1.47 \\
\hline & OF & 42.18 & 2.53 & 1.42 & 42.25 & 2.56 & 1.44 \\
\hline & $\mathrm{CF}$ & 43.69 & 2.72 & 1.48 & 43.95 & 2.77 & 1.50 \\
\hline & Mean & 41.650 & 2.503 & 1.428 & 41.880 & 2.548 & 1.444 \\
\hline \multirow{5}{*}{ T18 } & $\mathrm{NF}$ & 33.17 & 1.83 & 1.31 & 34.82 & 1.95 & 1.33 \\
\hline & IF & 40.07 & 2.30 & 1.37 & 40.39 & 2.34 & 1.38 \\
\hline & $\mathrm{OF}$ & 37.79 & 2.16 & 1.36 & 38.72 & 2.21 & 1.36 \\
\hline & $\mathrm{CF}$ & 41.23 & 2.41 & 1.39 & 41.46 & 2.46 & 1.41 \\
\hline & Mean & 38.065 & 2.173 & 1.357 & 38.848 & 2.239 & 1.371 \\
\hline \multicolumn{2}{|c|}{ Mean season } & 41.365 & 2.335 & 1.343 & 41.878 & 2.406 & 1.362 \\
\hline \multicolumn{2}{|c|}{$\begin{array}{l}\text { LSD 05 Fertilizer type } \\
n=24\end{array}$} & 0.639 & 0.056 & 0.037 & 0.639 & 0.056 & 0.037 \\
\hline \multicolumn{2}{|c|}{$\begin{array}{l}\text { LSD } 05 \text { Irrigation frequency } \\
\qquad \mathrm{n}=24\end{array}$} & 0.548 & 0.055 & 0.012 & 0.550 & 0.055 & 0.012 \\
\hline \multicolumn{2}{|c|}{ LSD 05 Season } & 0.388 & 0.039 & 0.008 & 0.389 & 0.039 & 0.008 \\
\hline
\end{tabular}

Egypt. J. Soil Sci. 54, No. 4 (2014) 


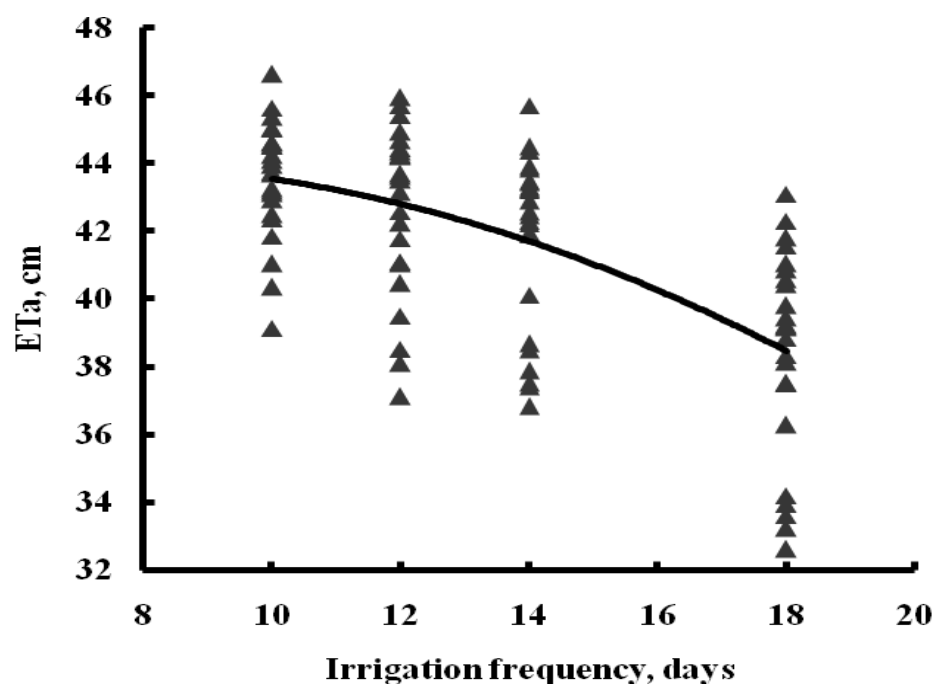

Fig. 1. The actual evapotranspiration of wheat crop as affected by irrigation frequency.

Concerning the effect of the studied fertilizers treatments on seasonal ETa of wheat crop under different irrigation frequencies are represented in Table 3 . The results showed that the addition of inorganic and organic fertilizers to the studied soil significantly increased seasonal ETa compared to the control treatment (without fertilizers). The average of seasonal ETa values varied from 43.4 to 37.6 $\mathrm{cm}$ for the first growing season and 43.9 to $38.5 \mathrm{~cm}$ for the second growing season, respectively. The highest value of seasonal ETa was obtained at combined fertilizers treatment $(\mathrm{CF})$ and the lowest value was obtained at control treatment (IF). The percentage increase values of the seasonal ETa relative to control treatment were $13.8,10.5 \& 15.3 \%$ for the first growing season and 12.9, $9.8 \& 14.7 \%$ for the second growing season, respectively. Consequently, the addition of combined between inorganic and organic fertilizers is the best treatment. The lowest increase was obtained at OF treatment. This lowest of seasonal ETa might be attributed to the addition of separately organic fertilizer is insufficient for fertilizer requirements of wheat crop during growing season.

The interaction between irrigation frequencies and fertilizers types on seasonal ETa values was significant (Table 3). The results revealed that irrigation interval every 10 days with combined fertilizers treatment $(\mathrm{CF})$ had the highest seasonal ETa value, while the irrigation interval every 18 days with organic fertilizer treatment (OF) had the lowest seasonal ETa value compared to the control treatment during studied growing seasons. These results indicated that the wheat crop irrigated by short irrigation interval $\leq 14$ days with fertilization by combined between inorganic and organic fertilizers increased seasonal ETa 
values. While, the wheat crop irrigated by the long irrigation interval > 14 days with separately organic fertilizer decreased seasonal ETa value. Consequently, the irrigation interval of wheat plants must be short interval of $\leq 14$ days with addition combined between inorganic and organic fertilizers.

Effect of irrigation frequencies and fertilizers types on wheat grain yield

Wheat grain yield values, ton/fed, as affected by irrigation frequencies are illustrated in Table 3 . The polynomial relationship between irrigation frequency time by days $(\mathrm{T})$ and wheat grain yield ton/fed under all treatments during studied growing seasons were estimated by CoHort computer program version 6.400 and demonstrated in Fig. 2. A highly significant relation was obtained with the coefficient of multiple determination is equal $0.418(n=95)$ and expressed in the following regression equation,

Wheat grain yield $=-0.0129 \mathrm{~T}^{2}+0.3464 \mathrm{~T}+0.1575$

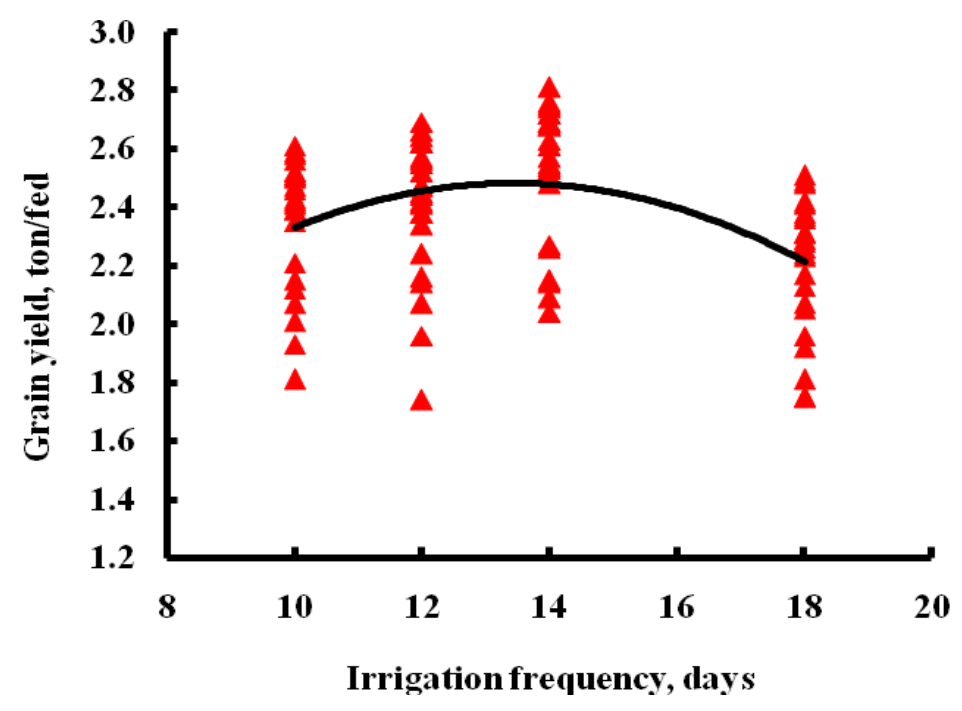

Fig. 2. The grain yield of wheat crop as affected by the irrigation frequency.

The results noticed that the irrigation frequencies significantly influenced grain yield for studied growing seasons. Wheat grain yield values increased by increasing irrigation interval from 10 to 14 days. While, the increasing irrigation interval to 18 days decreased wheat grain yield (Table 3 and Fig. 2). The wheat grain yield average ranged between 2.50 to 2.17 and 2.55 to 2.24 ton/fed for the first and second growing seasons, respectively. The highest wheat grain yield was obtained at plants irrigated every 14 days, while, the lowest grain yield was recorded at wheat plants irrigated every 18 days. Several researches suggested that increasing irrigation frequency could compensate for certain nutrient deficiencies and reduced grain yield of wheat plants irrigated less frequently may

Egypt. J. Soil Sci. 54, No. 4 (2014) 
be a result of nutrient shortages rather than water shortage (Buljovcic and Engels, 2001, Silber et al., 2003 and $\mathrm{Xu}$ et al., 2004). The results revealed that the irrigation interval every 10 or 18 days decreased the wheat grain yield as compared to irrigation interval 14 days (Table 3 ). The reason of the decrease obtained at the irrigation interval every 10 days might be attributed to the seasonal ETa was higher than the consumptive use of wheat crop and increased the storage water in the active root zone. This increase of water may be caused the partially poor aeration at active root zone and leaching of soil nutrients, consequently, the wheat grain yield values reduced. These results are agreed with that reported by Xiao et al. (2004). While, the decrease of wheat grain yield values obtained at the irrigation interval every 18 days might be attributed to the seasonal ETa value was less than the consumptive use of wheat crop, consequently, the wheat grain yield values reduced. The percentage increase of wheat grain yield values at irrigation interval every 12 and 14 days compared to the irrigation interval every 10 days were $1.0 \& 7.8 \%$ and $2.4 \& 6.6 \%$ for the first and second growing seasons, respectively. The percentage decrease of wheat grain yield values at irrigation interval every 18 days relative to the irrigation interval every 10 days were $6.4 \%$ for the studied growing seasons.

Concerning the effect of the studied fertilizers treatments on wheat grain yield, ton/fed, the data noticed that grain yield values significantly increased by addition of inorganic and organic fertilizers to the studied soil compared with the control treatment (without fertilizers) during studied growing seasons. These results are in agreement with Juo and Kangna (1989) who stated that the application of mineral fertilizer is an effective means of increasing yield, however, separately mineral fertilizer cannot sustain yields unless combined with other affordable and sustainable technology such as the use of compost or farmyard manure. Average wheat grain yield values varied from 1.98 to 2.53 ton/fed for the first growing season and 2.08 to 2.59 ton/fed for the second growing season, respectively. The highest value of wheat grain yield was obtained at combined fertilizers treatment $(\mathrm{CF})$ and the lowest value was obtained at the control treatment (NF). The percentage increase values of the wheat grain yield relative to control treatment were $24.5,19.1 \& 27.9 \%$ for IF, OF and CF fertilizers treatments during the first growing season and 23.1, $17.7 \&$ $26.2 \%$ for the same treatments during the second growing season, respectively. Consequently, the addition of combined between inorganic and organic fertilizers is the best treatment under studied treatments. The lowest increase was obtained at $\mathrm{OF}$ treatment. The addition of separately studied organic fertilizer is insufficient for fertilization requirements of wheat crop during growing season.

The interaction between irrigation frequencies and fertilizers types on wheat grain yield values was no significant effect. The results showed that the irrigation interval every 14 days with combined fertilizers treatment $(\mathrm{CF})$ had the highest grain yield value, while irrigation interval every 18 days with organic fertilizer treatment $(\mathrm{OF})$ had the lowest value compared to the control treatment during

Egypt. J. Soil Sci. 54, No. 4 (2014) 
studied growing season. These results indicated that the wheat crop irrigated by irrigation interval of 14 days with fertilization by combined between inorganic and organic fertilizers increased grain yield value, while, irrigated by the long irrigation interval > 14 days with separately organic fertilizer decreased grain yield values. Thus, the irrigation interval of wheat plants must be 14 days with addition combined between inorganic and organic fertilizers. The wheat plants irrigated by long irrigation interval might be subjected to water stress. Moreover, the separately organic fertilizer could not depress the harmful effect of water stress, then, the grain yield reduced.

\section{Water use efficiency (WUE)}

Concerning the effect of applied different irrigation frequencies on water use efficiency values, $\mathrm{kg} / \mathrm{m}^{3}$, of wheat crop during studied growing seasons under furrow irrigation system are shown in Table 3. Generally, the results showed that increasing irrigation frequency significantly decreased the water use efficiency values of wheat crop during studied growing seasons. The polynomial relationship between irrigation frequency time by days (T) and WUS, $\mathrm{kg} / \mathrm{m}^{3}$, for studied growing seasons of wheat crop were determined by CoHort computer program version 6.400 (Fig. 3). A highly significant relation was obtained with the coefficient of multiple determination is equal $0.540(n=95)$ and expressed in the following regression equation,

$$
\text { WUS }=-0.0057 \mathrm{~T}^{2}+0.1708 \mathrm{~T}+0.1285
$$

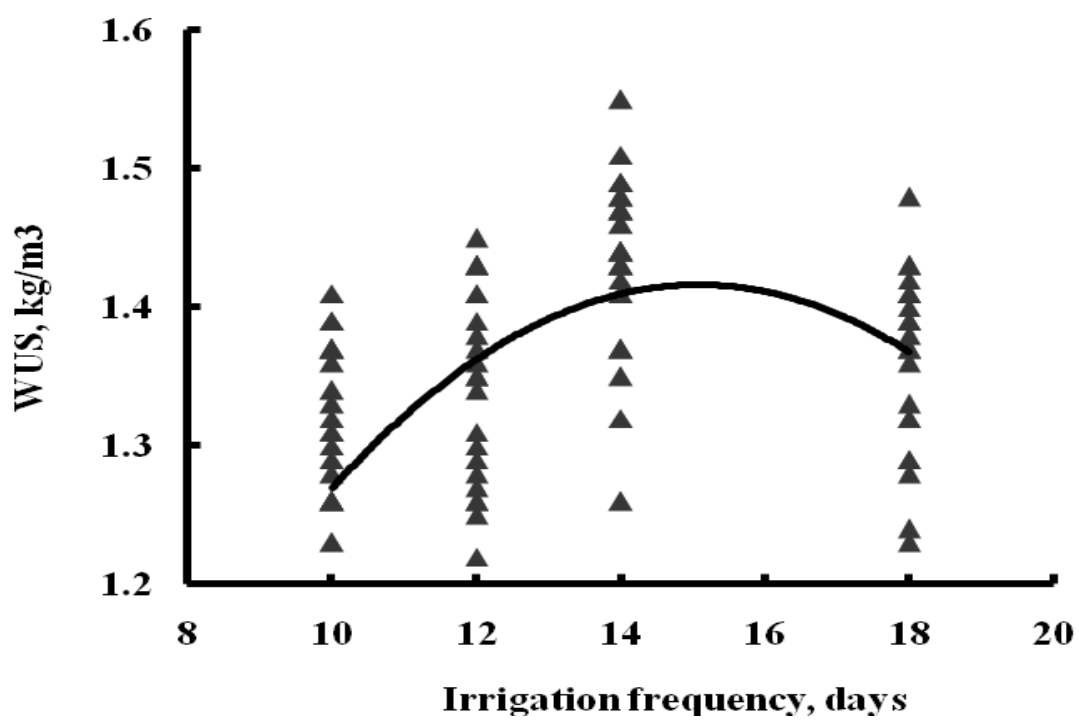

Fig. 3. The water use efficiency of wheat crop as affected by the irrigation frequency. 
The WUS average of wheat crop varied from 1.27 to 1.43 and 1.30 to 1.44 $\mathrm{kg} / \mathrm{m}^{3}$ for the first and second growing seasons, respectively. The highest value of wheat WUS was obtained at irrigation interval every 14 days and the lowest value was obtained at irrigation interval every 10 days under studied growing seasons. The percentage increase of water use efficiency values at irrigation interval every 12,14 and 18 days compared to the irrigation interval every 10 days were $3.4,8.6 \& 5.0 \%$ and 3.4, $7.8 \& 5.1 \%$ for the first and second seasons, respectively. Karam et al. (2003) stated that the plants were subjected to water stress had higher WUE values than that obtained for the plants without deficit irrigation water. The relatively higher wheat WUE obtained with irrigation interval of 18 days attributed to the ETa values were less than the consumptive use of wheat during the growing season and caused the wheat grain yield reduced.

Concerning the effect of the studied fertilizers treatments on water use efficiency of wheat crop under different irrigation frequencies are shown in Table 3. The results revealed that the addition of inorganic and organic fertilizers to the clay loam soil significantly increased wheat WUS compared to the control treatment (without fertilizers). The average values of wheat water use efficiency ranged between 1.26 to $1.39 \mathrm{~kg} /$ fed for the first growing season and 1.28 to $1.4 \mathrm{~kg} / \mathrm{m}^{3}$ for the second growing season, respectively. The highest value of wheat WUS was obtained at combined fertilizers treatment $(\mathrm{CF})$ and the lowest value obtained at control treatment (IF). The percentage increase values of the wheat WUS relative to control treatment were $13.8,10.5 \& 15.3 \%$ for IF, OF and CF fertilizers treatments during the first growing season and $23.1,17.7 \& 26.2 \%$ for the same treatments during the second growing season, respectively. This trend was almost similar to that obtained at the effect of inorganic and organic fertilizers treatments on wheat grain yield.

The interaction between irrigation frequencies and fertilizers types on water use efficiency values of wheat crop was no significant effect. The results revealed that the irrigation interval every 14 days with combined fertilizers treatment $(\mathrm{CF})$ had the highest wheat WUS value, while irrigation interval every 18 days with organic fertilizer treatment (OF) had the lowest value compared to control treatment (without fertilizers) during studied growing seasons. These results indicated that the wheat crop irrigated by irrigation interval of 14 days with fertilization by combined between inorganic and organic fertilizers increased wheat WUS, while, irrigated by the long irrigation interval of 18 days with separately organic fertilizer decreased WUS values. Consequently, the irrigation interval of wheat plants must be short interval of 14 days with addition combined between inorganic and organic fertilizers to the clay loam soil. The long irrigation interval more than 14 days, the wheat plants might be subjected to water stress. Also, the separately organic fertilizer is insufficient for fertilization requirements of wheat crop during growing season. Moreover, the organic fertilizer could not depress the harmful effect of water stress, then, the grain yield reduced. 


\section{References}

Al-Kaisi, M. M., Berrada, A. and Stack, M. (1997) Evaluation of irrigation scheduling program and spring wheat yield response in Southwestern Colorado. Agric. Water Manage. 34:137-148.

Allen, R.G., Pereira, L.S., Raes, D. and Smith, M. (1998) “Crop Evapotranspiration: Guidelines for Computing Crop Water Requirements", FAO Irrigation and Drainage, Paper No.56, Rome, Italy.

Buljovcic, Z. and Engels, C. (2001) Nitrate uptake ability by maize roots during and after drought stress. Plant Soil 229 (1): 125-135.

FAO. (1996) "Guidelines for Planning Irrigation and Drainage Investment Projects", FAO Investment Centre, Technical Paper No11.

Giriappa, S. (1983) “Water Use Efficiency in Agriculture”, Oxford \& IBH Publishing, C.O., New Delhi.

Hansen,V. W., Israelsen, D. W. and Stringharm, Q. E. (1979) “ Irrigation Principle and Practices", $4^{\text {th }}$ ed., John Wiley \& Sons, New York.

He, Y. and Li, R. (2004) Effect of the organo-inorgano-mixed fertilizer application on sugarcane yield and soil enzymatic activity. Sugar Crops China 4: 36-38.

Hussain, G. and Al-Jaloud, A. A. (1995) Effect of irrigation and nitrogen on water use efficiency of wheat in Saudi Arabia. Agric. Water Manage. 21:143-154.

Juo, A.S.R. and Kangna, B.T. (1989) Nutrient effects of modification of shifting cultivation in West Africa. In: "Mineral Nutrients in Tropical Forest and Savanacosystems”, J. Protor (Ed.), pp.289-300, Blackwell, Oxford.

Karam, F., Breidy, J., Stephan, C. and Rouphael, J. (2003) Evapotranspiration, yield and water use efficiency of drip irrigated corn in the Bekaa valley of Lebanon. Agric. Water Manage. 63(2):125-137.

Kang, S. Z., Zhang, L., Liang, Y. L., Hu, X.T., Cai, H. J. and Gu, B. J. (2002) Effects of limited irrigation on yield and water use efficiency of winter wheat in the loess plateau of China. Agric. Water Manage. 55:203-216.

Khadr, M. S., Abou El-Enein, R., Abd El-Sahafy, A., Zahran, F. A. and Zohry, A. A (2002) Sustainability of soil fertility status after 3 years crop rotation in sandy soils in Egypt. Agric. Res. 82: 220-225.

Kijne, J. W., Barker, R. and Molden, D. (2003) Water Productivity in Agriculture: Limits and opportunities for improvement. Wallingford, UK.

Klute, A. (1986) "Methods of Soil Analysis", Part $1,2^{\text {nd }}$ ed., ASA and SSSA, Madison, Wisconsin, USA.

Majumdar, D.U. (2002) "Irrigation Water Management, Principles and Practice", pp. 261-283, Prentice-Hall of India privet limited, New Delhi, India.

Egypt. J. Soil Sci. 54, No. 4 (2014) 
Marschner, H. (1995) “Mineral Nutrition of Higher Plants”, $2^{\text {nd }}$ ed., 889 p., Academic press, San Diego.

Nath, R., Chakraborty, P. K. and Chakraborty, A. (2001) Effect of climatic variations on yield of sesame (Sesamum indicum L.) at different date of sowing. J. Agron. Crop Sci. 186: 97-102.

Norwood, C. A. (2000) Dry land winter wheat as affected by previous crops. Agron. J. 92: 121-127.

Page, A. L. (1982) "Methods of Soil Analysis", Part 2, $2^{\text {nd }}$ ed., ASA and SSSA, Madison, Wiscansin, USA.

Pala, M., Ryan, J., Zhang, H., Singh, M. and Harris, H. C. (2007) Water use efficiency of wheat-based rotation systems in a Mediterranean environment. Agric. Water Manage. 93:136-144.

Prasad, R. (1996) Cropping systems and sustainability of agriculture. Indian Farm. 46:39-45.

Silber, A., Xu, G., Levkovitch, I., Soriano, S., Bilu, A. and Wallach, R. (2003) High fertigation frequency: The effects on uptake of nutrients, water and plant growth. Plant Soil 253: 467-477.

Sendecor, G. W. and Cocheran, W. G. (1980) "Statistical Methods", $7^{\text {th }}$ ed., Iowa State Univ. Press, Ames, Iowa, USA.

Van Duivenbooden, N., De Wit, C.T. and Van Keulen, H. (1996) Nitrogen, phosphorous and potassium relations in five major cereals reviewed in respect to fertilizer recommendations using simulation modeling. Fert. Res. 44: 37-49.

Xu, G., Levkovitch, I., Soriano, S., Wallach, R. and Silber, A. (2004) Integrated effect of irrigation frequency and phosphorus level on lettuce: $\mathrm{P}$ uptake, root growth and yield. Plant Soil 263: 297-309.

Xiao, J. , Lei, T. W., Jiang, P. F. and Yu, Y.D. (2004) Effects of water quality in furrow irrigation on corn yield and soil salinity. An ASAE/CSAE Meeting Presentation Paper No.042037, 1-4 August Ottawa, Ontario, Canada.

Zhang, H. P., Wang, X. Y., You, M. Z. and Yu, C. M. (1999) Water-yield relations and water-use efficiency of winter wheat in the North China plain. Irrigation Sci. 19: 3745 .

(Received 5/2/2014;

accepted 21/9/2014) 


$$
\begin{aligned}
& \text { تأثير فترات الري والتسميد على البخر - نتح الفعلي وإنتاجية القـح }
\end{aligned}
$$

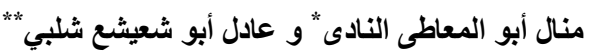

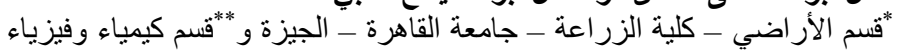

$$
\begin{aligned}
& \text { التربة - مركز بحوث الصحر اءء - القاهرة - مصر. }
\end{aligned}
$$

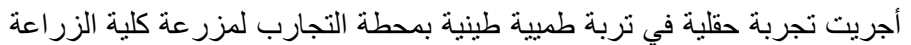

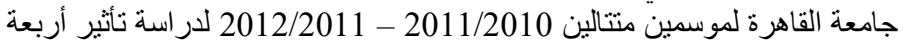
فترات ري و ثناثة أنواع من التسميد بالإضافة إلى معاملة المقارنة (بدون تسميد)

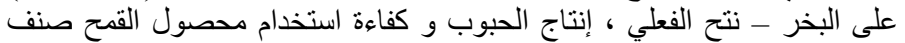

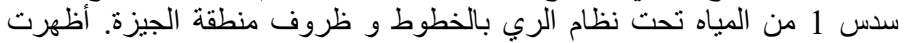

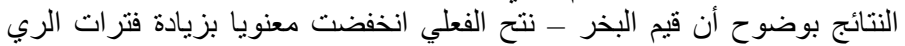

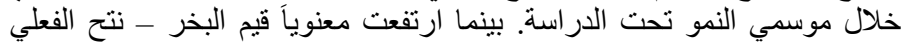

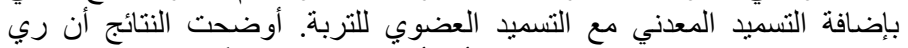

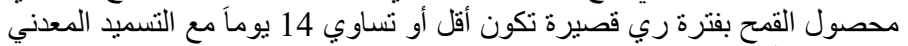

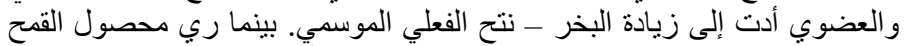

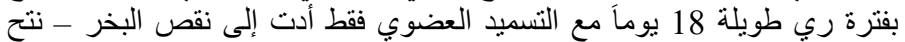

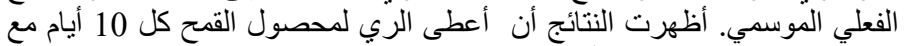

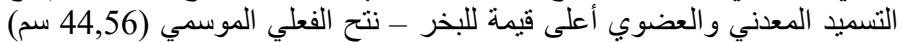
بينما أعطى الري كل 18 يوماً أقلى قيمة للبخر - نتح الفحلي الموسي الفي الموسي (37,79سم).

أوضحت النتائج أن تأثثير فترات الري على محصول الحبوب كان تأثير معنوي

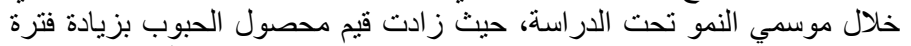

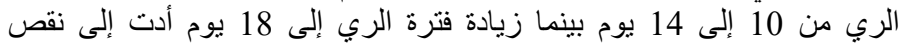

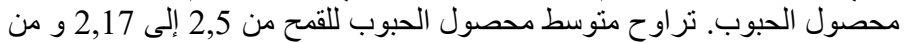

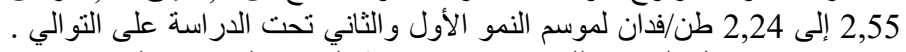

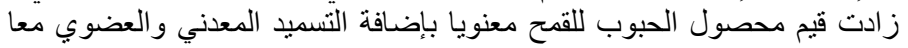

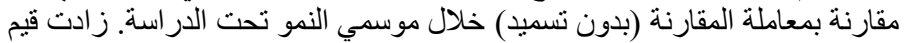

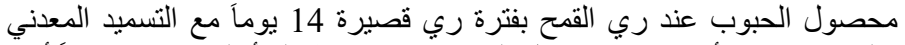

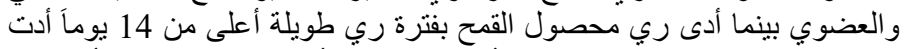

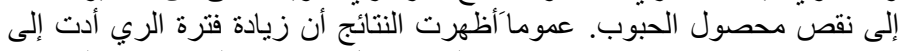

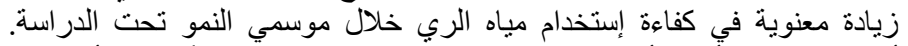

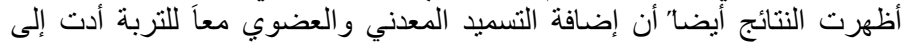

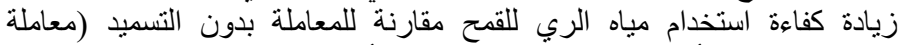

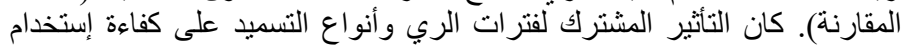

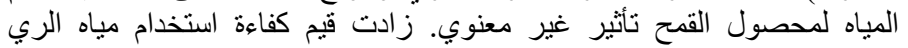

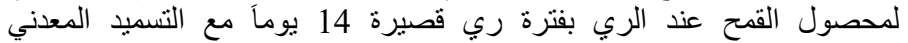

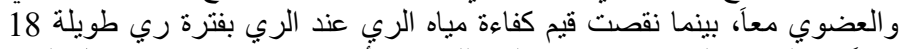

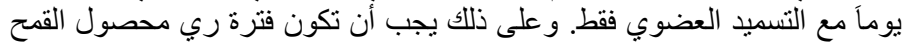

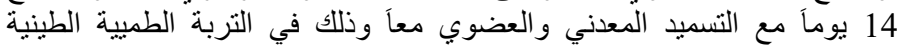

وظروف منطقة الجيزة. 